\title{
Rare finding of a giant ischioanal lipoma
}

\author{
Authors: Vignesh Narasimhan FRACS ${ }^{1}$, Daniel Wein MBBS ${ }^{1}$, Amrish Rajkumar \\ MBBS$^{2}$, Chip Farmer FRACS ${ }^{1}$, Satish Warrier FRACS ${ }^{1,2}$. \\ Affiliations: ${ }^{1}$ General Surgical Unit, The Alfred Hospital, Prahran, Melbourne, \\ ${ }^{2}$ Peter MacCallum Cancer Centre, Parkville, Melbourne.
}

Correspondence: Mr Satish Warrier, Department of General Surgery, Alfred Hospital, Commercial Road, Victoria 3004, Melbourne, Australia.

Email: satish96101@yahoo.com

Telephone: +61390762000

Mobile: +61488054238

Facsimile: +61390763902

Short title: Rare finding of a giant ischioanal lipoma

Disclosures/Conflicts of interest/Scholarships: Dr Vignesh Narasimhan, Dr Daniel Wein, Dr Amrish Rajkumar, Mr Chip Farmer and Mr Satish Warrier have no disclosures or conflicts of interest. This research paper has not been presented or published elsewhere.

Dr. Vignesh Narasimhan is a PhD candidate and is a recipient of a RACS foundation for surgery small projects grant for 2017 for a different project.

This manuscript has been read and approved by all authors. It contains a case report and discussion (word count 725 words) and three figures.

Ethical standards: This case report complies with the current laws of Australia.

This is the author manuscript accepted for publication and has undergone full peer review but has not been through the copyediting, typesetting, pagination and proofreading process, which may lead to differences between this version and the Version of Record. Please cite this article as doi: $10.1111 /$ ans.14197

This article is protected by copyright. All rights reserved. 


\section{Case Report: Rare finding of a giant ischioanal lipoma}

A 54 year old lady presented to the colorectal clinic with a 12 month history of an increasing lump in her buttock, with symptoms alternating between faecal urgency and obstructed defaecation during this period.

She had no history of PR blood loss or weight loss. Her past history included an appendicectomy, previous bladder sling operation and two vaginal deliveries. Her last colonoscopy was two years ago, and was reported to be normal. She was otherwise in good health. There was no family history of colorectal cancer.

On examination, there was a palpable, soft swelling in the left ischiorectal area, which was palpable externally and on digital rectal examination (DRE). There was no abnormality of the rectal mucosa.

She was investigated with anal manometry and pudendal nerve latency testing, computed tomography (CT) and Magnetic resonance imaging (MRI) of her pelvis. Manometry confirmed normal anal tone, with evidence of left pudendal nerve neuropathy. The pudendal nerve latency was $2.0 \mathrm{~ms}$ on the right side and $3.2 \mathrm{~ms}$ on the left (Normal $<2.6 \mathrm{~ms}$ ). Pre-operative anal resting pressure (mean 50 
mmHg, maximum $75 \mathrm{mmHg}$ ) and squeeze pressure (97 mmHg, maximum 111 $\mathrm{mmHg}$ ) were both normal.

Colonoscopy did not reveal any mucosal lesions. CT scan and MRI revealed a $12 \mathrm{x}$ $6 \times 5 \mathrm{~cm}$ well circumscribed, encapsulated, fat containing soft tissue density in the left ischiorectal space, elevating the left levator muscle. It had mass effect, displacing puborectalis and the anal canal to the right. There was no imaging evidence of rectal obstruction. Its overall appearances were suggestive of a lipoma.

Given her symptoms and increasing size of the mass, she underwent operative excision of this lesion. Operative technique involved making a hemicircumferential incision in the ischioanal space with the patient in the prone position. The external anal sphincter (EAS) was identified and dissection remained lateral to it. The EAS was followed up to the levator muscle. The lesion shelled out with a combination of blunt and sharp dissection. It had gross appearances in keeping with a lipoma. The pudendal bundle was identified and preserved. The lesion was completely removed and the wound was closed primarily over a drain tube. The patient made an uneventful recovery. She did not have any perianal numbness, bladder or bowel dysfunction post-operatively. As she did not report any symptoms post operatively, no formal post-operative anal manometry and nerve latency testing were undertaken.

This article is protected by copyright. All rights reserved. 
Histology confirmed the lesion to be a large lipoma.

The ischioanal fossa is a pyramidal space bordered by the anal canal medially, obturator internus with its overlying fascia laterally, the levator muscle superiorly, the transverse perineal muscles anteriorly and the skin of the perineum inferiorly ${ }^{1}$. Tumours of the ischioanal space are very rare, with published literature largely based on case reports, and small case series ${ }^{2-4}$. Tumours in this region usually present as perineal or labial masses. Large lesions that compress the rectum or urogenital organs can cause symptoms such as constipation, dysuria, dyspareunia or obstructed defaecation ${ }^{4-7}$. Tumours can be congenital, acquired or neoplastic.

Congenital lesions include gardner's cysts, epidermal cysts, tailgut cysts and hamartomas. These are benign lesions, that have characteristic appearances on MRI, and have little malignant risk ${ }^{5}$. Neoplastic lesions range from lipomas, teratoma, angiomyxoma, nerve sheath tumours and sarcomas. Metastases to the area are exceedingly rare. Teratomas are generally seen in the neonatal population. Lipomas are benign, with similar signal to surrounding subcutaneous tissue. However, they can be difficult to differentiate from well-differentiated liposarcomas on imaging alone ${ }^{1}$.

This article is protected by copyright. All rights reserved. 
Due to the depth of these lesions, diagnosis cannot be made on clinical grounds alone. Imaging test are vital to diagnosis. If the lesion is superficial, ultrasound is useful to assess vascularity and proximity to surrounding structures. For deeper lesions MRI or CT is preferred. MRI is superior to CT due to superior soft tissue contrast enhancement and differentiation ${ }^{1,5}$. Core Biopsy is useful in differentiating malignant from benign lesions. In the case of the patient above, a benign core biopsy would not have excluded a well-differentiated liposarcoma.

Ischioanal fossa lesions are very rare, with no clear guidelines on management. Imaging is vital to aid diagnosis, as clinical assessment is usually inadequate to confirm the diagnosis. MRI is the preferred modality for deeper lesions, and it provides good soft tissue enhancement. If imaging and biopsy are unable to exclude malignancy, surgical excision, usually via the posterior approach is the mainstay of treatment.

References

1. Tappouni RF, Sarwani NI, Tice JG, Chamarthi S. Imaging of Unusual Perineal Masses. American Journal of Roentgenology. 2011;196(4):W412-W20. 2. Purysko A, Coppa C, Kalady M, Pai R, Filho H, Thupili C, et al. Benign and malignant tumors of the rectum and perirectal region. Abdom Imaging. 2014;39(4):824-52.

This article is protected by copyright. All rights reserved. 
3. Nassif M, Trabulsi N, Bullard Dunn K, Nahal A, Meguerditchian A-N. Soft tissue tumors of the anorectum: rare, complex and misunderstood. J Gastrointest Oncol. 2013;4(1):82-94.

4. Buchs N, Mortensen N, Richard G, Gibbons M, George B. Management of tumors of the ischiorectal fossa: the role of percutaneous biopsy. Diseases of the colon and rectum. 2015;58(10):938-42.

5. Filho E, Lopes de Carvalho A, Fredrico de Oliveira Costa P, al e. Resection of ischiorectal fossa tumors-surgical technique. Journal of Coloproctology. 2016;36(3):179-83.

6. Karakousis C. Resection of tumors of the ischiorectal fossa. Atlas of operative procedures in surgical oncology: Springer New York; 2014. p. 383-7. 7. Trill J, Garcia J, Moreno I, Pina J, Tobaruela E, Barquin J, et al. Surgical excision of ischiorectal fossa tumors. Surgical Science. 2016;7:461-5.

Figures

Fig. 1(a-c). MRI scan showing the soft tissue mass in the left ischioanal fossa. The mass effect is pushing the anal canal to the right. The dashed white lines demonstrates the lipoma with a 'dumbbell' component extending posterior to the anal canal. The white arrow in (c) is the anal canal. 
Fig. 2(a-d). Intra-operative images demonstrating exploration of the left ischioanal fossa. Fig.2a-2c demonstrates the lipoma shelling out in its entirety. $2 d$ demonstrates the intact external anal sphincter.

Fig $3(a, b)$. Fig. 3a demonstrating specimen post removal. The path of the anal canal has been shown, with the 'dumbbell' component extending posterior to the anal canal. Fig.3b showing the closed ischiorectal wound. 

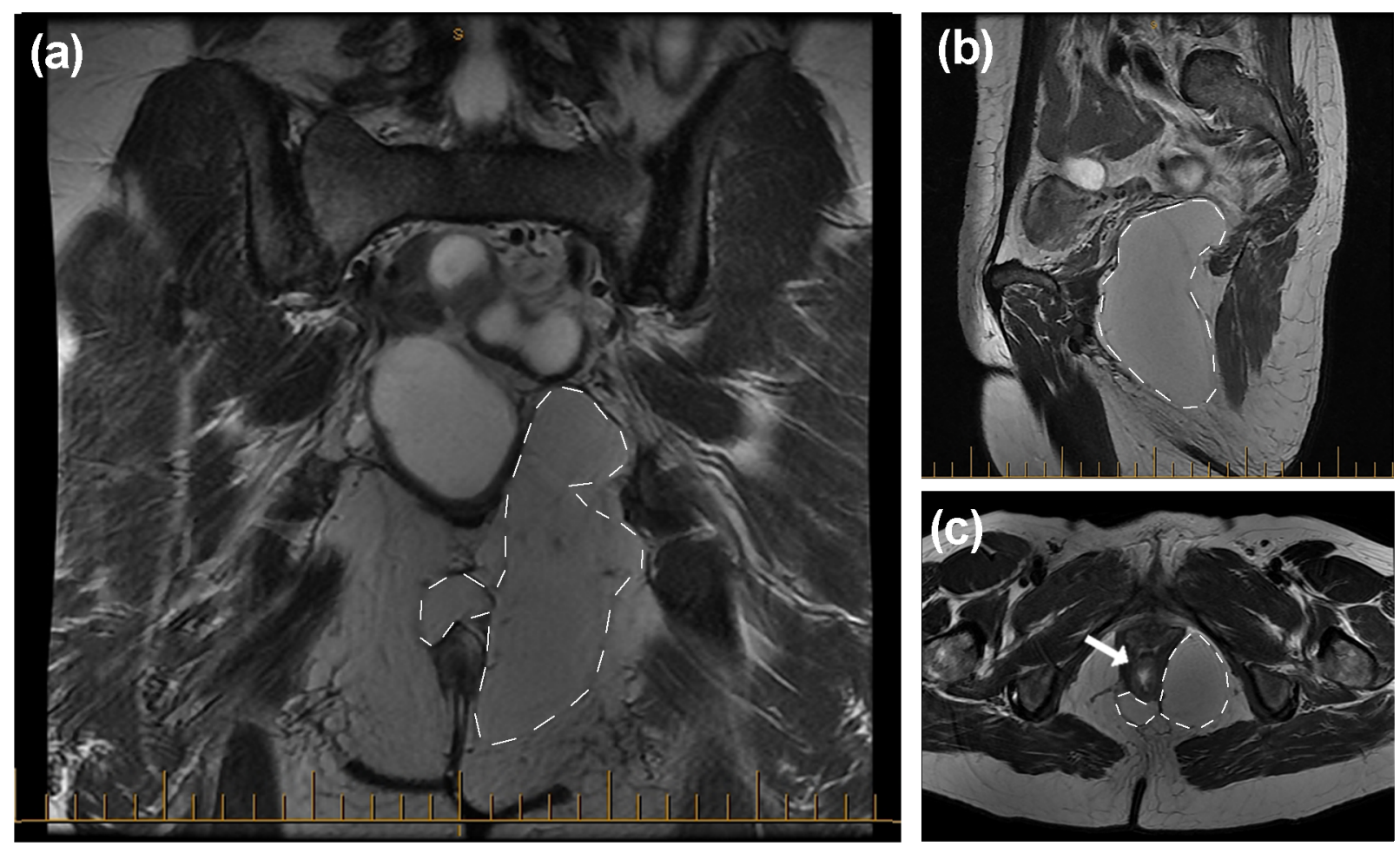

fig 1_new.tif

This article is protected by copyright. All rights reserved. 

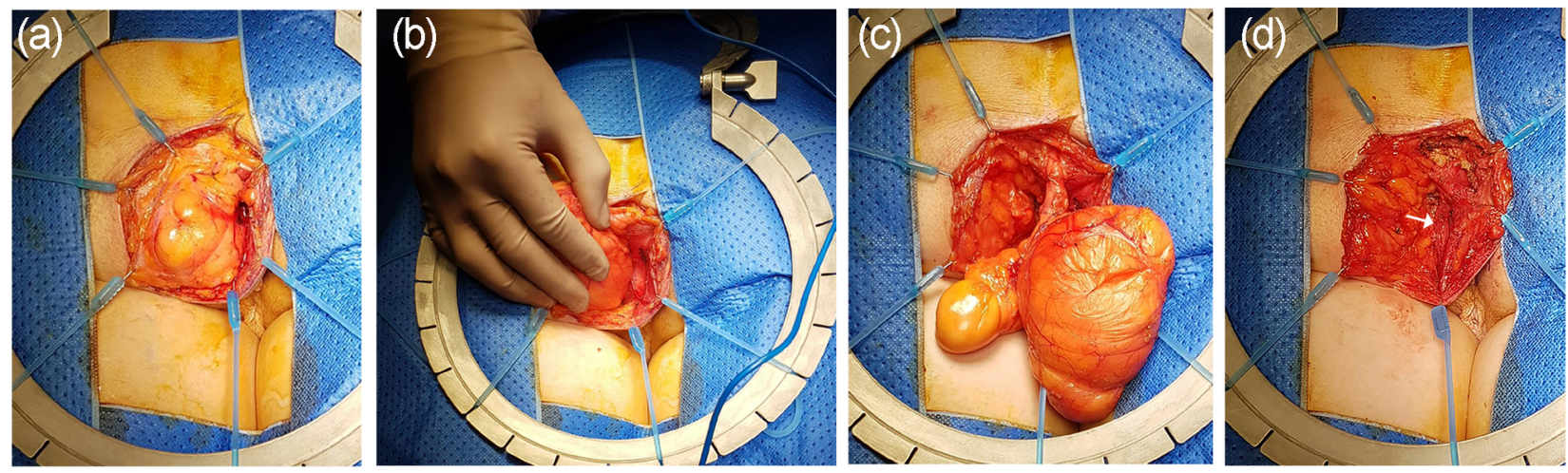

fig.2.tif

This article is protected by copyright. All rights reserved. 

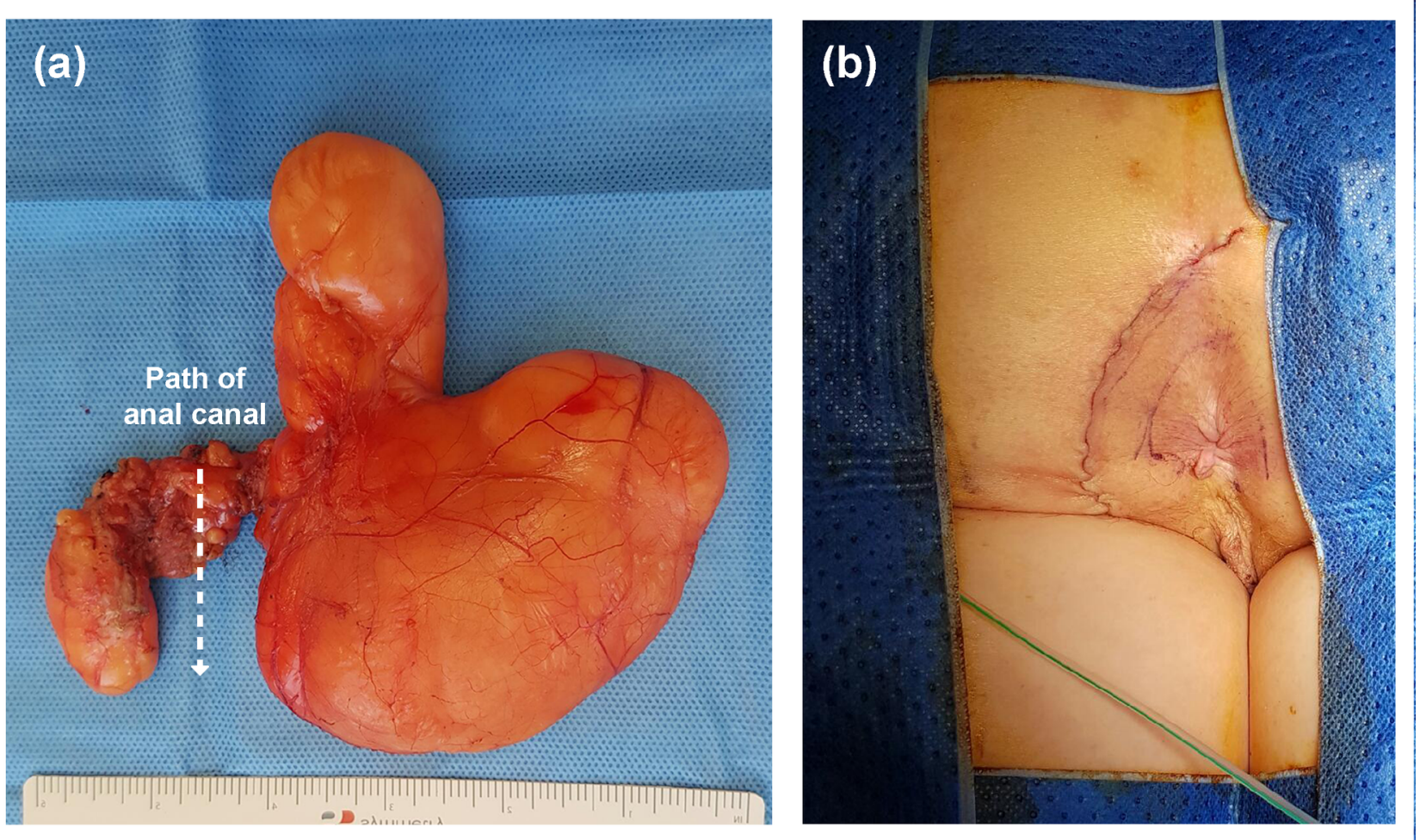

fig.3_new.tif

This article is protected by copyright. All rights reserved. 


\section{University Library}

\section{- M M I E R R V A gateway to Melbourne's research publications}

Minerva Access is the Institutional Repository of The University of Melbourne

\section{Author/s:}

Narasimhan, V;Wein, D;Rajkumar, A;Farmer, C;Warrier, S

Title:

Rare finding of a giant ischioanal lipoma

Date:

2019-05-01

Citation:

Narasimhan, V., Wein, D., Rajkumar, A., Farmer, C. \& Warrier, S. (2019). Rare finding of a giant ischioanal lipoma. ANZ JOURNAL OF SURGERY, 89 (5), pp.604-606. https:// doi.org/10.1111/ans.14197.

Persistent Link:

http://hdl.handle.net/11343/293417 